\title{
The Arrangement of Dual Citizenship of the Indonesian Diaspora: A Legal and Human Rights Perspective
}

\author{
Made Nurmawati ${ }^{1}$, I Nengah Suantra ${ }^{2}$ \\ ${ }^{1}$ Faculty of Law, Udayana University, E-mail : made_nurmawati@unud.ac.id \\ ${ }^{2}$ Faculty of Law, Udayana University E-mail : nengah_suantra@unud.ac.id
}

\begin{tabular}{l} 
Info Article \\
\hline Received: $25^{\text {th }}$ February 2020 \\
Accepted: $26^{\text {th }}$ September 2020 \\
Published: $30^{\text {th }}$ September 2020 \\
Keywords: \\
Diaspora; Dual Citizenship; \\
Human Rights; Law. \\
Corresponding Author: \\
Made Nurmawati \\
Email: \\
made_nurmawati@unud.ac.id \\
DOI: \\
10.24843/JMHU.2020.v09.i03. \\
p03
\end{tabular}

Info Article

Accepted: $26^{\text {th }}$ September 2020

Keywords:

Diaspora; Dual Citizenship

Corresponding Author:

Made Nurmawati

Email:

DOI:

\section{Introduction}

According to the 1933 Montevideo Convention, one element of the state is a permanent population. The population is divided into citizens and foreigners. Bagir Manan stated that the population is a constitutive element of the state's existence. ${ }^{1}$ This means that the existence of citizens is very important as an element. The state cannot exist if it does not have citizens. On the other hand, there will never be a citizen if there is no state. The reciprocal legal relationship between the state and citizens of the state is called citizenship, as a very important basis for the state to distinguish who are citizens and foreigners. $^{2}$

The advancement of science and technology in the era of globalization has made interactions and relations between countries and people in the world very open and easy to do. The world seems to be borderless. Steger stated that globalization in the form of economic, political, cultural, and global environmental relations is boundless

\begin{abstract}
various parts of the world. Indonesian diaspora groups are aggressively fighting for their citizenship status in order to have dual citizenship. Law No. 12 of 2006 concerning Citizenship of the Republic of Indonesia has not regulated dual citizenship identify and analyze the dual citizenship position of the Indonesian diaspora in the Indonesian Citizenship Law. The research method used is normative legal research. The study suggested that citizenship status is very important because it relates to issues of rights and obligations. The bipartite status However, it is not the time to grant unlimited dual citizenship status because first, it needs an in-depth study of the implications of social, economic, cultural, political, security, and legal aspects as well as changes to the relevant related laws and regulations.
\end{abstract}

${ }^{1}$ Manan, B. (2009). Hukum Kewarganegaraan Indonesia dalam UU No. 12 Tahun 2006. Yogyakarta: FH UII Press, p. 1-3.

2 Rajab, A. (2018). Peran Perubahan Undang-Undang Kewarganegaraan dalam Mengakomodir Diaspora untuk Peningkatan Kesejahteraan Masyarakat. Jurnal Konstitusi, 14(3), p. 540. 
and the existing restrictions become useless. ${ }^{3}$ In this era of globalization, knowledge, communication, culture, capital and goods have crossed national borders and have spread throughout the world. ${ }^{4}$ Indonesia as one of the most densely populated countries in the world can not be denied has been utilizing the development of information technology in many activities based on the advancement of the internet system. ${ }^{5}$ Although globalization brings a good thing on one side, on the other hand, it also has a detrimental effect. For example, a migration that is motivated by a culture that is different from the culture of the destination country can have an impact that is incompatible with the destination country because migration can be caused due to individual desires of a person based on individual reasons such as marriage, duty, work, economic needs, as well as education. On the other side, migration happens due to factors beyond his will, for example, due to security problems, disasters, wars, and so on.

Iman Santoso ${ }^{6}$ argued that in contrast to previous migration, in the global era international migration was mostly carried out voluntarily without coercion, and international migration had turned into transnational migration. Transnational migration is the migration of people from various levels with various problems of life from one territory to several other countries for temporary or permanent residence, which is of various dimensions with various impacts, in an effort to find opportunities to improve the quality of life. Migrants move from one or several countries to another and continuously choose a better life. The final goal is to determine a better country or region for themselves and their families.

In the destination country, immigrants establish relations and cooperation with fellow immigrants and their countries of origin in order to create better-living conditions in the economy, politics, society, and culture. This community is the embryo of the diaspora. ${ }^{7}$ Diaspora is related to the spread of people from their country of origin to other countries. ${ }^{8}$ In this context, it can be interpreted as the movement of people from one country to another. However, the people of the diaspora still adhere to their culture, habits, and religion in a new place. ${ }^{9}$ In other words, diaspora is different from migration, wherein the diaspora these people still maintain or have very strong ties

3 Arief, A. (2018). Definisi Globalisasi Menurut 25 Ahli. Retrieved from https://www.scribd.com/doc/78357992/Definisi-Globalisasi-Menurut-25-Ahli, diakses 14 desember 2018.

${ }^{4}$ Santoso, M. I. (2014, October). Diaspora Migrasi Internasional dan Kewarganegaraan Ganda. Makalah Disampaikan Pada Seminar Diaspora Dan Dinamika Konsep Kewarganegaraan Di Indonesia. Fakultas Hukum, Universitas Indonesia, Depok. Tanggal 14 Oktober 2014, p. 8.

${ }^{5}$ Dharmawan, N. K. S., Kasih, D. P. D., \& Stiawan, D. (2019). Personal data protection and liability of internet service provider: a comparative approach. International Journal of Electrical and Computer Engineering, 9(4), 3177.

6 Santoso, M.I, op.cit., p. 9.

${ }^{7}$ Romdiati, H. (2015). Globalisasi migrasi dan peran diaspora: Suatu kajian pustaka. Jurnal Kependudukan Indonesia, 10(2), p. 90.

8 Cambridge Dictionary. (2018). Translations of Diaspora. Retrieved from http://dictionary.cambridge.org/dictionary/english/diaspora\#translations., Diakses 14 desember 2018.

${ }^{9}$ Amazine. (2018). Apa itu Diaspora? Fakta, Sejarah \& Informasi Lainnya. Retrieved from http://www.amazine.co/25264/apa-itu-diaspora-fakta-sejarah-informasi-lainnya/, Diakses 14 desember 2018). 
with their homeland. In relation to Indonesia, the Indonesian diaspora is Indonesian people who are scattered to various parts of the world, bringing Indonesian cultural identity to various parts of the world. In 2012 the Indonesian Diaspora established a forum so-called the Indonesian Diaspora Network (IDN). The purpose of this IDN is basically to develop Indonesia in various sectors through a global network.

In the context of the Indonesian Diaspora, they come from various regions in Indonesia, such as the Javanese diaspora, the Makassar diaspora, and the Balinese diaspora. For example, the Balinese Diaspora, which consists of Balinese residents, is spread across various types of work around the world, such as Australia, America, Japan, and France. They still maintain kinship and love for the country. This happens because they adhere to the outlook on the life of their people, such as their beliefs, habits, and culture. ${ }^{10}$ Wherever they are they still maintain their cultural identity.

According to Dino Pati Djalal, the Indonesian Diaspora is grouped into four, namely: Indonesian citizens with an Indonesian passport, Indonesian citizens who change citizenship to become foreigners in the country where they live, people of Indonesian descent who are married to foreigners, and Indonesian lovers. ${ }^{11}$ By understanding that groupings, it can be argued that in terms of citizenship status, they may be Indonesian citizens, foreign nationals, or dual. The Indonesian Diaspora demands that they have dual citizenship status including their children. The existing Indonesian Citizenship Law is deemed incapable of protecting their rights to citizenship status, and also because in reality in the era of globalization it requires progressive laws, which are able to answer various problems and challenges that exist according to the times. Dual citizenship, especially for children who are the result of a mixed marriage, has been adopted in the Indonesian Citizenship Law. They are allowed to have limited dual citizenship. Previous studies have shown that there are pros and cons among practitioners and the public regarding dual citizenship. May Lim Charity emphasized that it is necessary to give access to foreigners so that they have dual status as Indonesian citizens. On the other hand, for Indonesian citizens who work in a foreign country, there is nothing to lose if given the opportunity to become a dual. ${ }^{12}$ This is a result of globalization and also due to remittances or foreign exchange that are deposited into their home countries. World Bank data for 2012 shows that workers sent foreign exchange to Indonesia around \$ 7.2 billion. ${ }^{13}$ This means that the Indonesian diaspora has high economic potential and provides a large enough contribution to state

${ }^{10}$ Narottama, N., Arun, A. A., \& Arianty, S. (2017). Proses pembentukan identitas budaya nasional Dan promosi pariwisata indonesia di eropa (studi kasus diaspora bali di perancis). Jurnal Kepariwisaatan dan Hospitalitas, 1, p. 183.

${ }^{11}$ KBRI Kuala Lumpur. (2018). Diaspora Indonesia Konektivitas Menjadi Jiwa Nasionalisme. Retrieved from http://idn.kbrikualalumpur.org/index.php/80-templatedetails/general/110-diaspora-indonesia konektivitas-menjadi-jiwa-nasionalisme, Diakses 14 desember 2018.

12 Charity, M. L. (2016). Urgensi Pengaturan Kewarganegaraan Ganda Bagi Diaspora Indonesia. Jurnal Konstitusi, 13(4), p. 824.

13 Sipahutar, T. (2018). RI diaspora expected to boost economy Retrieved from http://www.thejakartapost.com/news/2013/08/20/ri-diaspora-expected-boosteconomy.html., Diakses 14 desember 2018. 
revenue. The promotion of Indonesian tourism was also carried out by performing Indonesian arts and culture in European countries . ${ }^{14}$

Satya Arinanto argues that the Indonesian diaspora plays a significant role in national development because as a non-state actor through remittances and plays a role as human capital, skills, wealth, and network..$^{15}$ The Indonesian Diaspora in the United States helps the country in conducting Gastronomy diplomacy to establish economic cooperation with the United States. Where they established the Indonesian Diaspora Network as a network to help more effective relations between government agencies and the diaspora and inter-country relations by introducing Indonesia through food, for example, Rendang \& co., Participating in food festivals and bazaars. ${ }^{16}$ On the other hand, there are concerns over the application of bipatride for the Indonesian Diaspora, especially in relation to terrorism and immigration security. ${ }^{17}$ Other concerns are that the dark side is more prominent, among others: tax avoidance, the emergence of crime, the level of nationalism against Indonesia, and from the aspect of national security in Indonesia. ${ }^{18}$ The results of the study also show that in principle, dual citizenship is not recognized, because it adheres to the principle of single citizenship, even though citizenship status, inclusive, dual citizenship is a human right. ${ }^{19}$

Therefore, having dual nationality, both limited and unlimited is like a double-edged sword. On the one hand, it can have a positive impact on them, but on the other hand, it can also have a negative impact. The positive side of dual citizenship, among them, is that they get legal rights from the two countries and close the possibility of being stateless (stateless), they can move freely in the two countries where they become citizens, they can also choose the passport they want. . One of the negative sides is the issue of loyalty to the state, and legal protection for them in case of a problem. Therefore, it is interesting to examine: first, what is the urgency of citizenship status for someone? and second, how is the dual citizenship status of the Indonesian Diaspora in terms of law and human rights?

\section{Research Method}

This study uses normative legal research methods with statutory, analytical, conceptual, and philosophical approaches to primary, secondary, and tertiary legal materials. National and international legal materials related to citizenship after being identified, classified, and interpreted are then analyzed descriptively and analytically, and finally concluded.

${ }^{14}$ Narottama, N., Arun, A. A., \& Arianty, S., Op. Cit. p.180.

${ }^{15}$ Muliadi, M. (2019). Analisis Hukum Status Kewarganegaraan Ganda Menurut UndangUndang Nomor 12 Tahun 2006 Tentang Kewarganegaraan. Res Nullius Law Journal, 1(1).p. 1.

${ }^{16}$ Abhiyoga, N., Hartoni. (2019). Upaya Diaspora Indonesia di Amerika Serikat dalam Meningkatkan Brand Awardness Melalui Food Festival. Jurnal Ilmu Hubungan Internasional, MANDALA, Vol.2, No. 2, Juli-Desember 2019, p. 219.

${ }^{17}$ Sibuea ,H.Y.P, (2018). Loc. Cit.

${ }^{18} \mathrm{Ibid}, \mathrm{p} .4$.

${ }^{19}$ Nurmawati, M. (2016). Status Kewarganegaraan Ganda Tidak Terbatas Bagi Anak Diaspora Dalam Perspektif Hak Asasi Manusia, Denpasar : Udayana Press. p. 40. 


\section{Results and Discussion}

\subsection{The Urgency of Citizenship Status}

The demand for dual citizenship status was widely discussed after the formation of the Indonesian Diaspora Network in 2012 and also the case of Gloria Natapradja Hamel who failed to become a member of Paskibraka and the case of Archandra Taher as Minister of Energy and Mineral Resources, who is known to have nationality from another country. The demands filed by the diaspora include: not losing their Indonesian citizenship status if the diaspora gets citizenship in another country (dual citizenship); easiness and freedom for Indonesian diaspora, especially Ex-Indonesian citizens to enter or leave and settle in the territory of the Indonesian state, for example, the ease of obtaining special visas, permanent or limited stay permits; and there are flexible regulations for Indonesian diaspora who wish to invest, get jobs as experts, purchase property and other. ${ }^{20}$ In this regard, the Indonesian Citizenship Law as a major role in the welfare of society, accommodating the interests of all parties and all Indonesian people for the realization of welfare for the community. ${ }^{21}$

Why is it important for someone to have the citizenship status of a country? Citizens are closely related to citizenship status. Hector S. De Leon \& Emilio E. Lugue Jr. emphasized that citizens are members of a democratic society who enjoy full civil and political rights and receive protection at home and abroad, as long as they remain loyal to their country. ${ }^{22}$ The Indonesian Citizenship Law stipulates that a citizen is: a citizen of a country determined by statutory regulations. Therefore, every person is not automatically a citizen of a country, but if he fulfills the conditions specified in the laws of the country concerned.

Citizenship that is inherent in a person is very important so that his position as a legal subject is recognized and is legally guaranteed and obtains certain constitutional rights. Citizenship also shows a person's identity and identifier to be able to fully participate in society. Someone who is apatride will find obstacles and even cannot enjoy the rights of a country including the legal protection of a country. Moreover, under international law, only "citizens" have the full right to enter or leave and stay within a country. Every citizen and his country are correlative. Citizens as supporters of the State, while the State is obliged to protect its citizens. Thus, a person's citizenship status is related to two basic aspects, namely: they will have a clear legal status, and also have social status, meaning that their position as citizens is socially recognized.

\footnotetext{
${ }^{20}$ Abdillah, J. (2017). Solusi Kebijakan Pemerintah Terhadap Tuntutan Dwikewarganegaraan (Solution of Government Policy To Dual Citizenship Demand). Jurnal Ilmiah Kebijakan Hukum, 10(3), p. 260, DOI : http:/ / dx.doi.org/10.30641/kebijakan.2016.V10.257-267

21 Ibid., p. 541.

22 Paulus, B. P. (1983). Kewarganegaraan RI ditinjau dari UUD 1945, khususnya kewarganegaraan peranakan Tionghoa: tinjauan filosofis, historis, yuridis konstitusional (Doctoral dissertation, Universitas Gadjah Mada). p. 42.
} 
In international law, citizenship status provides facilities in the form of certain benefits to citizens, among others: ${ }^{23}$

a. Right to diplomatic protection.

b. State responsibility. The state is responsible for its citizens to commit acts of breaking the law.

c. Prohibition for the state to refuse the return of its citizens [Article 12 paragraph (4) ICCPR].

d. d. allegiance, that nationality determines the attitude of a person to declare his oath of loyalty.

e. extradition, that citizenship is one of the conditions in the implementation of extradition. A country, based on the principle of non-extradition of nationality, can refuse a request for extradition, unless it is stipulated otherwise based on an international agreement.

f. The validity of legal jurisdiction, for example in Criminal Law there is an active national principle, that the provisions in the Criminal Law of a country are applied to its citizens wherever they are domiciled.

The Universal Declaration of Human Rights 1948 and International Covenant on Civil and Political Rights (ICCPR) $1966^{24}$ strictly regulate the rights and interests of individuals and groups to promote, respect, protect, facilitate and provide human rights fulfillment. ${ }^{25}$ Article 5 of the UDHR and Article 24 of the ICCPR expressly stated that every person, including every child, has the right to citizenship and no one is arbitrarily deprived of or denied the right to change his nationality.

A.W. Bradley and K.D. Ewing stated that citizenship status correlates a person with another in the relationship between countries, it also determines the validity of the legal jurisdiction of a country. ${ }^{26}$ Citizenship status is vital not only for the country but also for the person concerned. For the state, it is clear that citizenship is one of the fundamental elements for the existence of the state, while for citizens it will bring consequences both juridically and sociologically. They will enjoy, among others, juridical, social, economic rights and obtain legal protection from their country wherever they are on this earth. Dual citizenship facilitates them so they can enjoy these rights from both countries.

Theoretically, citizenship status is divided into apatride, which is a stateless person; single nationality, meaning that a person only has one nationality; bipatride or dual nationality, that a person has dual nationality; and multipatride, namely citizenship of

23 Palguna, I.D.G. (2014), makalah Doktrin "Genuine Link" Dalam Hukum Internasional Berkenaan dengan Kewarganegaraan, Catatan dari Nottebohm Case (Liechtenstein v.Guatemala), disampaikan pada Seminar Nasional Diaspora dan Dinamika Konsep Kewarganegaraan di Indonesia yang diselenggarakan oleh Fakultas Hukum Universitas Udayana bekerjasama dengan Indonesian Diaspora Network, 14 Oktober 2014, p. 2.

${ }^{24}$ International Covenant on Civil and Political Rights, sudah diratifikasi dengan Undang-Undang Nomor 12 Tahun 2005.

${ }^{25}$ Sumitro, S. (2018). Implementasi Hak Asasi Manusia Dalam Sistem Peradilan Pidana Indonesia. Lex Et Societatis, 6(1)., p. 80.

${ }^{26}$ Asshiddiqie, J. (2011). Kewarganegaraan: Konstruksi Hukum Keindonesiaan. Makalah untuk simposium tentang ke-indonesiaan dan Kewarganegaraan, Lembaga Ilmu Pengetahuan, Oktober 2011., p. 3. 
more than two countries. Basically, the Indonesian Citizenship Law does not recognize dual citizenship or statelessness. The dual nationality granted to children is an exception. ${ }^{27}$ It can be considered that the Indonesian Citizenship Law adheres to the doctrine of "perpetual allegiance" which is actually feudal in nature and will not survive the face of modernity and the swift currents of globalization; as expressed by Spiro that "the common law doctrine perpetual allegiance, a last legal vestige of feudal conceptions of the relationship between sovereign and subject, could not survive modernity and increasingly global mobility. ${ }^{28}$

In relation to the demands of the Indonesian diaspora, the Indonesian government has issued a policy that makes it easy for Indonesian Diaspora through the Indonesian Citizenship Law and Law no. 6 of 2011 concerning Immigration. Article 4 of the Indonesian Citizenship Law provides bipatride status for children who are results of mixed marriages until they are 18 years old or are not yet married. The child is required to choose one of his nationalities and is given a period of 3 years (up to 21 years of age) to determine his nationality. However, parents of children with dual nationalities misunderstood the 21 year age limit. They assume that the choice of a new nationality begins when the child is 21 years old. As a consequence, many children lose Indonesian citizenship, which can even become stateless. ${ }^{29}$

The Immigration Law provides immigration facilities to the Indonesian diaspora, especially ex-Indonesian citizens and their descendants, which include: free visit visas, Visa on Arrival, one-time or multiple-trip visit visas, limited stay visa, change of status a visit residence permit becomes a limited stay permit, and a limited stay permit status changes to a permanent residence permit.

\subsection{Dual Citizenship from a Legal and Human Rights Perspective}

Indonesia guarantees the existence, respect, and actualization of human rights as a manifestation of the rule of law as stipulated in Article 1 paragraph (3) of the 1945 Constitution of the Republic of Indonesia. The state guarantees the protection of human rights based on the law, not on a certain will, condition, or political tendency. ${ }^{30}$ Laws are enacted in order to protect human rights. Taking into account the urgency of protecting human rights, human rights become one of the contents of the constitution as a guarantee for the state of the constitutional rights of its citizens. ${ }^{31}$ The right to citizenship is one type of human rights, one of which is dual citizenship. The

27 Ponco Aji, K. (2018)., Op. Cit. p. 80. Lihat juga Jazuli, A. (2017). Diaspora Indonesia dan dwi kewarganegaraan dalam perspektif Undang-Undang kewarganegaraan Republik Indonesia. JIKH, 11(1), p. 100, DOI: 10.30641/kebijakan.2019.V13.359-378.

28 Prameswari, Z. W. A. W., \& Negara, D. H. T. (2015). Ratio Legis Dan Dampak Pengaturan Kewarganegaraan Ganda Dalam Undang-Undang Kewarganegaraan Republik Indonesia. Science and Technology, 8(12), p. 371. DOI : 10.30641/kebijakan.2019.V13.359-378.

${ }^{29}$ Gayo, A. A. (2019). Problematika Status Kewarganegaraan Anak Melampaui Batas Usia 21 Tahun (Studi Kasus Provinsi Bali). Jurnal Penelitian Hukum De Jure, 19(3), p. 273. DOI: http: 10.30641/dejure.2019.V19.269-284.

30 Go, L. (2014). Pendidikan Tentang Pencegahan Kekerasan terhadap Perempuan dalam Dimensi Kejahatan Siber. Pandecta: Jurnal Penelitian Ilmu Hukum, 9(1),. P. 5.

31 Asrun, A. M. (2016). Hak Asasi Manusia Dalam Kerangka Negara Hukum: Catatan Perjuangan di Mahkamah Konstitusi. Jurnal Cita Hukum, 4(1). p. 134. 
Indonesian Citizenship Law was formed based on human rights as seen from the Preamble and Explanation section. Then in the torso more specifically accommodated.

Related to the issue of dual nationality, it can be divided into Limited and unlimited dual citizenship. Indonesia only adheres to the limited principle of bipatride, namely for children the result of mixed marriages [Article 6 paragraph (1) of the Indonesian Citizenship Law]. Children can bipatride only up to 18 years of age or have been married. Then Article 2 paragraph (1) Regulation of Minister of Law and Human No. M.HH-19.AH.10.01 Year 2011 stipulates that: bipatride children must choose one of the nationalities no later than 3 (three) years after the age of 18 years or already married. Thus, children can become limited bipatride until the age of 21 years, after which they must make a choice of law as an Indonesian citizen or foreigner. To obtain dual citizenship, several qualifications must be met, in accordance with the nationality laws and regulations.

There are 3 (three) factors that can cause a person to have dual citizenship, namely: (1) the application of the principle of different citizenship, (2) mixed marriage, and (3) naturalization. Each country has its own regulations regarding the principle of dual citizenship. Some countries apply this principle, such as the United States of America (USA), Canada, Ghana, India, Pakistan, the Philippines, China, France, Sweden, Germany, those in Central and Eastern Europe, and others. There are also countries that do not have dual citizenship, such as Indonesia, Japan, those in Southern Europe, Monaco, Andorra, and so on. For example, dual citizenship is the result of the application of the principle of different citizenship. A married couple with Indonesian citizenship gave birth to children in the jurisdiction of the USA. The child who was born has Indonesian citizenship based on the principle of ius sanguinis (Law of the Blood) adopted by Indonesia. In addition, they also obtain United States citizenship based on the principle of ius soli (Law of The Soil) applied by the State.

from a legal and human rights perspective, dual citizenship results in a person being subject to two legal jurisdictions, namely the law of the country of origin and the law where they obtain the nationality of both countries. The implication of bipatride is also related to the rights and obligations of every citizen. ${ }^{32}$ In general, there are 5 (five) principles for obtaining citizenship, namely: 'Citizenship by birth'; citizenship by descent; 'Citizenship by naturalization'; 'Citizenship by registration'; and 'citizenship by incorporation territory'. Law No.12 of 2006 stipulates the general principles of citizenship, namely the ius sanguinis principle, the ius soli principle, and the mixed principle. In general, there are two principles as the basis for determining the position of personnel, namely the principle of personality (Lex patriae) and the principle of Lex domicile. The determination of citizenship status based on the principle of personality can be carried out on the basis of the principle of descent and the principle of birthplace. Meanwhile, the domicile principle is related to the principle of ius soli. This means that a person's place of birth (ius soli) is used as the basis for determining his citizenship.

An example of the cases in Indonesia related to dual citizenship is the case of Archandra Tahir, the former Minister of Energy and Mineral Resources. He turned out to have US citizenship, which led to her dismissal as a minister. If Ardchandra is appointed to become a minister, while he also holds the status of a foreigner (US), this

${ }^{32} \mathrm{Ibid}$, 
would be contrary to Article 22 of Law No. 39 of 2008, that the requirements as a minister, among others, must be Indonesian citizens, and obey God Almighty. So clearly and firmly it is said that the status must be Indonesian citizen, not a foreigner or dual nationality. Several related laws concern to this phenomenon such as Law no. 2 of 2018; Supreme Court Law, Law no. 13 of 1985 in conjunction with Law No. 3 of 2009; The Supreme Audit Agency Law, namely Law No. 5 of 1973 in conjunction with Law No. 15 of 2006; Constitutional Court Law, namely Law No. 24 of 2003 jo Law No. 4 of 2014; The Judicial Commission Law is Law No. 22 the Year 2004 jo Law No. 18 the Year 2011, and Law No. 7 of 2017 concerning General Elections. Of course, the existence of these provisions must be changed/replaced if you want to give positions to those who have dual nationalities. Granting dual citizenship from other legal aspects also raises the issue of whether their rights are the same as those of Indonesian citizens who have only one nationality. Or are their rights limited to certain rights such as social, economic, political, land ownership, or education rights?33

Citizenship status that is attached to a person is part of human rights. This has been recognized and confirmed in national and international legal rules. In Indonesian law such as: Article 26 (1), Article 27 (1) 28 D (4), and Article 28E (1) of the Indonesian Constitutional Law; Article 26 of the Law No. 39 of 1999 concerning Human Rights.; Law No. 12 of 2006 concerning Citizenship; Republic of Indonesia Human Rights Regulation No. 22 of 2012 concerning Procedures for Registration and Application of Immigration Facilities for Children with Multiple Nationalities born after August 1, 2006; and Regulation of Minister of Law and Human Rights No. M.HH-19.AH.10.01 Year 2011, concerning Procedures for Choosing Citizenship for Children with Multiple Nationalities. In the international level, this matter is regulated under several legal instruments such as : Article 15 of the Universal Declaration of Human Rights, International Covenant on Civil and Political Rights, Convention on the Nationality of Married Women, Convention on the Elimination of All types of Discrimination Against Women, Convention on the Reduction of Statelessness, and Convention relating to the Status of Stateless Persons.

The above legal provisions indicate that citizenship status is part of human rights. Thus, the universal right to citizenship is a human right that is recognized by all countries. But for dual citizenship, there is universally no obligation for the state to implement it, it depends on the policy/law politics of each country. For Indonesia, granting unlimited dual citizenship status requires various in-depth studies from various aspects. In this regard, the Minister of Foreign Affairs of the Republic of Indonesia, Retno Lestari Priansari Marsudi explained that Indonesia does not recognize dual citizenship as regulated in Article 26 paragraph 1 of the 1945 Constitution. The basic idea of implementing dual citizenship is to bring back successful citizens abroad to build their own country. The Indonesian Diaspora is a very potential asset to strengthen the country's defense abroad through citizenship. Lily Andayani stated that "... the empowerment of Indonesian Diaspora, in a sustainable way, provides an important meaning in strengthening Indonesian

33 Harianto. (2018). Kewarganegaraan Ganda Siapa Punya. Retrieved from https://nasional.tempo.co/read/799001/kewarganegaraan-ganda-siapa punya, , Diakses 14 desember 2018. 
diplomacy broadly to fight for and protect Indonesian national interests, including national defense ${ }^{34}$

However, it is a necessity to provide limited dual citizenship status, especially in relation to certain rights for diaspora holders of Indonesian passports and former Indonesian citizens. As for the descendants of Indonesian citizens, the Citizenship Law has been given the right to have limited dual citizenship. Indeed, the politics of Indonesian citizenship law does not yet require the granting of permanent dual citizenship. However, seeing the potential of the Indonesian diaspora, the recognition of dual citizenship for them is one of the efforts to empower Indonesian human resources. ${ }^{35}$

\section{Conclusion}

Having citizenship status is very important because it relates to issues of rights and obligations. An Indonesian citizen has full rights and obligations in relation to the state. Meanwhile, foreigners support limited rights and obligations. Likewise, with the status of a citizen, someone has a juridical identity and gets legal protection wherever they are. Thus, having the bipatride status will get the rights and obligations, protection, and identity of the two countries. From a legal and human rights perspective, bipatride is subject to the legal jurisdiction of the two countries. The Indonesian state adheres to the status of its personnel based on the principle of nationality, as stipulated in Article $16 \mathrm{AB}$ (algemeene bapalingen van wetgeving) so that a person is subject to the provisions of national law, wherever they are. Foreigners living in Indonesia are subject to Indonesian national law as long as they have the capacity as Indonesian residents and also comply with national laws. Citizenship status that is attached to a person is part of human rights, in accordance with national and international legal instruments. However, dual citizenship is not a universal human right because its actualization depends on the policies of each country.

\section{References}

\section{Books}

Asshiddiqie, J. (2011). Kewarganegaraan: Konstruksi Hukum Keindonesiaan. Makalah untuk simposium tentang ke-indonesiaan dan Kewarganegaraan, Lembaga Ilmu Pengetahuan.

Manan, B. (2009). Hukum Kewarganegaraan Indonesia dalam UU No. 12 Tahun 2006. Yogyakarta: FH UII Press.

Nurmawati, M. (2016). Status Kewarganegaraan Ganda Tidak Terbatas Bagi Anak Diaspora Dalam Perspektif Hak Asasi Manusia, Denpasar: Udayana Press.

\footnotetext{
${ }^{34}$ Andayani, L. (2020). Indonesian Diaspora Empowerment: A Concept In Strengthening Diplomacy For National Defense. Jurnal Pertahanan: Media Informasi ttg Kajian \& Strategi Pertahanan yang Mengedepankan Identity, Nasionalism \& Integrity, 6(1), p. 115. DOI. 10.33172/Jp.v.6il.371.

${ }^{35}$ Banyualam Permana, R. (2014). Penerapan Dwi Kewarganegaraan Di Indonesia: Menuju Masyarakat Transnasional Indonesia. JURIS: JKIHUI 4, p. 65.
} 


\section{Journals}

Abdillah, J. (2017). Solusi Kebijakan Pemerintah Terhadap Tuntutan Dwikewarganegaraan (Solution of Government Policy To Dual Citizenship Demand). Jurnal Ilmiah Kebijakan Hukum,10(3), h.260, DOI : http:/ / dx.doi.org/10.30641/kebijakan.2016.V10.257-267

Abhiyoga, N., Hartoni. (2019). Upaya Diaspora Indonesia di Amerika Serikat dalam Meningkatkan Brand Awardness Melalui Food Festival. Jurnal Ilmu Hubungan Internasional, MANDALA 2(2).

Andayani, L. (2020). Indonesian Diaspora Empowerment: A Concept In Strengthening Diplomacy For National Defense. Jurnal Pertahanan: Media Informasi ttg Kajian $\mathcal{E}$ Strategi Pertahanan yang Mengedepankan Identity, Nasionalism \& Integrity, 6(1), DOI. 10.33172/Jp.v.6il.371.

Asrun, A. M. (2016). Hak Asasi Manusia Dalam Kerangka Negara Hukum: Catatan Perjuangan di Mahkamah Konstitusi. Jurnal Cita Hukum, 4(1).

Banyualam Permana, R. (2014). Penerapan Dwi Kewarganegaraan Di Indonesia: Menuju Masyarakat Transnasional Indonesia. JURIS: JKIHUI 4.

Charity, M. L. (2016). Urgensi Pengaturan Kewarganegaraan Ganda Bagi Diaspora Indonesia. Jurnal Konstitusi, 13(4).

Dharmawan, N. K. S., Kasih, D. P. D., \& Stiawan, D. (2019). Personal data protection and liability of internet service provider: a comparative approach. International Journal of Electrical and Computer Engineering, 9(4).

Gayo, A. A. (2019). Problematika Status Kewarganegaraan Anak Melampaui Batas Usia 21 Tahun (Studi Kasus Provinsi Bali). Jurnal Penelitian Hukum De Jure, 19(3), h. 273. DOI: http: 10.30641/dejure.2019.V19.269-284.

Go, L. (2014). Pendidikan Tentang Pencegahan Kekerasan terhadap Perempuan dalam Dimensi Kejahatan Siber. Pandecta: Jurnal Penelitian Ilmu Hukum, 9(1).

Jazuli, A. (2017). Diaspora Indonesia dan dwi kewarganegaraan dalam perspektif Undang-Undang kewarganegaraan Republik Indonesia. JIKH, 11(1), DOI: 10.30641/kebijakan.2019.V13.359-378.

Muliadi, M. (2019). Analisis Hukum Status Kewarganegaraan Ganda Menurut Undang-Undang Nomor 12 Tahun 2006 Tentang Kewarganegaraan. Res Nullius Law Journal, 1(1).

Narottama, N., Arun, A. A., \& Arianty, S. (2017). Proses pembentukan identitas budaya nasional Dan promosi pariwisata indonesia di eropa (studi kasus diaspora bali di perancis). Jurnal Kepariwisaatan dan Hospitalitas, 1.

Prameswari, Z. W. A. W., \& Negara, D. H. T. (2015). Ratio Legis Dan Dampak Pengaturan Kewarganegaraan Ganda Dalam Undang-Undang Kewarganegaraan Republik Indonesia. Science and Technology, 8(12), DOI : 10.30641/kebijakan.2019.V13.359-378.

Rajab, A. (2018). Peran Perubahan Undang-Undang Kewarganegaraan dalam Mengakomodir Diaspora untuk Peningkatan Kesejahteraan Masyarakat. Jurnal Konstitusi, 14(3).

Romdiati, H. (2015). Globalisasi migrasi dan peran diaspora: Suatu kajian pustaka. Jurnal Kependudukan Indonesia, 10(2).

Sumitro, S. (2018). Implementasi Hak Asasi Manusia Dalam Sistem Peradilan Pidana Indonesia. Lex Et Societatis, 6(1). 


\section{Dissertation}

Paulus, B. P. (1983). Kewarganegaraan RI ditinjau dari UUD 1945, khususnya kewarganegaraan peranakan Tionghoa: tinjauan filosofis, historis, yuridis konstitusional (Doctoral dissertation, Universitas Gadjah Mada).

\section{Articles}

Palguna, I.D.G. (2014), makalah Doktrin "Genuine Link" Dalam Hukum Internasional Berkenaan dengan Kewarganegaraan, Catatan dari Nottebohm Case (Liechtenstein v.Guatemala), disampaikan pada Seminar Nasional Diaspora dan Dinamika Konsep Kewarganegaraan di Indonesia yang diselenggarakan oleh Fakultas Hukum Universitas Udayana bekerjasama dengan Indonesian Diaspora Network, 14 Oktober 2014.

Santoso, M. I. (2014, October). Diaspora Migrasi Internasional dan Kewarganegaraan Ganda. Makalah Disampaikan Pada Seminar Diaspora Dan Dinamika Konsep Kewarganegaraan Di Indonesia. Fakultas Hukum, Universitas Indonesia, Depok. Tanggal 14 Oktober 2014.

\section{Online}

Amazine. (2018). Apa itu Diaspora? Fakta, Sejarah \& Informasi Lainnya. Retrieved from http://www.amazine.co/25264/apa-itu-diaspora-fakta-sejarah-informasilainnya/, Diakses 14 desember 2018.

Arief, A. (2018). Definisi Globalisasi Menurut 25 Ahli. Retrieved from https://www.scribd.com/doc/78357992/Definisi-Globalisasi-Menurut-25-Ahli, diakses 14 desember 2018.

Cambridge Dictionary. (2018). Translations of Diaspora. Retrieved from http://dictionary.cambridge.org/dictionary/english/diaspora\#translations., Diakses 14 desember 2018.

Harianto. (2018). Kewarganegaraan Ganda Siapa Punya. Retrieved from https://nasional.tempo.co/read/799001/kewarganegaraan-ganda-siapa punya, , Diakses 14 desember 2018.

KBRI Kuala Lumpur. (2018). Diaspora Indonesia Konektivitas Menjadi Jiwa Nasionalisme. Retrieved from http://idn.kbrikualalumpur.org/index.php/80template-details/general/110-diaspora-indonesia konektivitas-menjadi-jiwanasionalisme, Diakses 14 desember 2018.

Sipahutar, T. (2018). RI diaspora expected to boost economy Retrieved from http:/ / www.thejakartapost.com/news/2013/08/20/ri-diaspora-expected-boosteconomy.html., Diakses 14 desember 2018. 